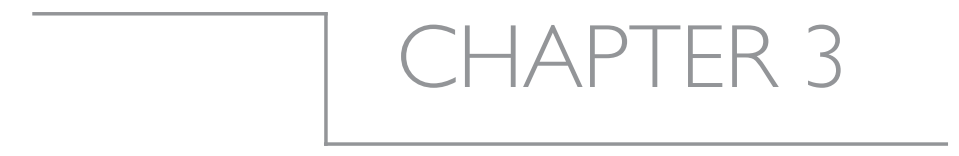

\title{
Climate and climate CHANGe
}

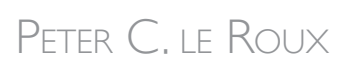

The climate of the sub-Antarctic islands, along with their geographic isolation and biotic influences, makes them unique (French \& Smith 1985; Smith \& French 1988). The highly oceanic nature of this climate, coupled with the strong influence of passing frontal systems creates an unusual climate where freezing temperatures can occur during any month, gale force winds blow most weeks and daily temperature maxima can occur during the middle of the night. The sub-Antarctic climate is even more interesting, however, because of the climate change currently being experienced in the region. Relative to the region's buffered thermal regime, the rapid warming in the sub-Antarctic represents an exceptional change (e.g. the rise in temperature over the last 50 years is roughly equivalent to $50 \%$ of the daily temperature range; Smith \& Steenkamp 1990).

Due to its duration and the scarcity of similar datasets from the sub-Antarctic, the continuous weather record available from Marion Island since the 1950s provides a valuable and unique dataset. Marion Island's meteorological station was originally established to improve weather forecasting capabilities for South Africa, but has also helped to characterize the climate of the mid-latitudes of the Southern Ocean, and to describe recent climate change in the region.

\footnotetext{
S.L. Chown E P.W. Froneman (eds.) The Prince Edward Islands $\bullet$ Land-Sea Interactions in a Changing Ecosystem, 39-64
} 


\section{I The hyper-oceanic climate}

Marion Island has one of the most oceanic climates in the world, termed hyperoceanic by Van Zinderen Bakker (1978) and Smith \& Steenkamp (1990). As on other sub-Antarctic islands, the Southern Ocean moderates daily and annual temperature fluctuations due to its high thermal inertia (Schulze 1971; Bonan 2002). In consequence, Marion Island has low daily (mean difference between maximum and minimum temperatures $<2^{\circ} \mathrm{C}$ in winter; $<3{ }^{\circ} \mathrm{C}$ in summer) and seasonal (mean difference between mean winter and summer temperatures is $4.1^{\circ} \mathrm{C}$ ) thermal variability (Fig. 3.1; Schulze 1971; Smith \& Steenkamp 1990). Indeed, the oceanic climate of the Southern Hemisphere sub-polar terrestrial habitats distinguishes them from their Northern Hemisphere equivalents, which have continental climates with pronounced seasonality (French \& Smith 1985). The dominant effect of the Southern Ocean on Marion Island's temperatures is evident from the tight correlation between sea surface temperature and air temperature (linear correlation coefficient for mean monthly temperatures $=0.54 ;$ Smith \& Steenkamp 1990), with the island's mean annual air temperature differing little from mean sea surface temperatures (Schulze 1971; Smith \& Steenkamp 1990; see also Mélice et al. 2003). Similarly, the island's narrow mean daily temperature range of only $1.9^{\circ} \mathrm{C}$ corresponds with the low amplitude of the daily temperature cycle in the surrounding open ocean (Schulze 1971). Another result of the ocean's thermal inertia is that the island's temperature regime lags behind solar radiation inputs, with the warmest temperatures being recorded in January, February and March, despite maximum solar radiation being received in December (Fig. 3.1a; Schulze 1971; see also Huntley 1970). Similarly, on average, daily temperature maxima are recorded just after midday, although can occur at nearly any time of the day due to the influence of frontal systems (Fig. 3.1b; Schulze 1971). A consequence of Marion Island's low mean annual temperature and buffered thermal variability is that sub-zero temperatures can be experienced during any month of the year, with temperatures regularly crossing the $0^{\circ} \mathrm{C}$ threshold (Schulze 1971; see also Boelhouwers et al. 2003). No meteorological records exist for Prince Edward Island, but its climate is assumed to be similar to that of Marion Island, although with slightly lower diurnal temperature variation due to its smaller size (Schulze 1971), as well as a weaker Föhn effect and less orographic cloud due to its lower maximum altitude (see below).

The close association between Marion Island's air and sea surface temperatures not only buffers temperature variation, but is possibly also responsible for some of the medium-term variation in the island's temperatures. This is likely since the passage of warm and cold oceanic eddies probably affects air temperatures on the island (warm or cold circulation anomalies take 1-2 months to drift past the island; see Mélice et al. 2003). Over a longer time scale, changes in the latitudinal position of the sub-Antarctic front (as well as other ocean fronts in the vicinity) could affect the island's temperature, because waters passing the island will be warmer when the front is located to the south of the island than 
when the front is north thereof (Ansorge \& Lutjeharms 2000; Pakhomov \& Chown 2003). The Antarctic Circumpolar Wave (ACW) could also influence inter-decadal variation in sea surface temperatures around Marion Island (Mélice et al. 2005), although it is not yet possible to confidently attribute longterm variation in sea surface temperatures to the ACW due to the relatively short duration (e.g. satellite data) and sparse nature (e.g. meteorological stations

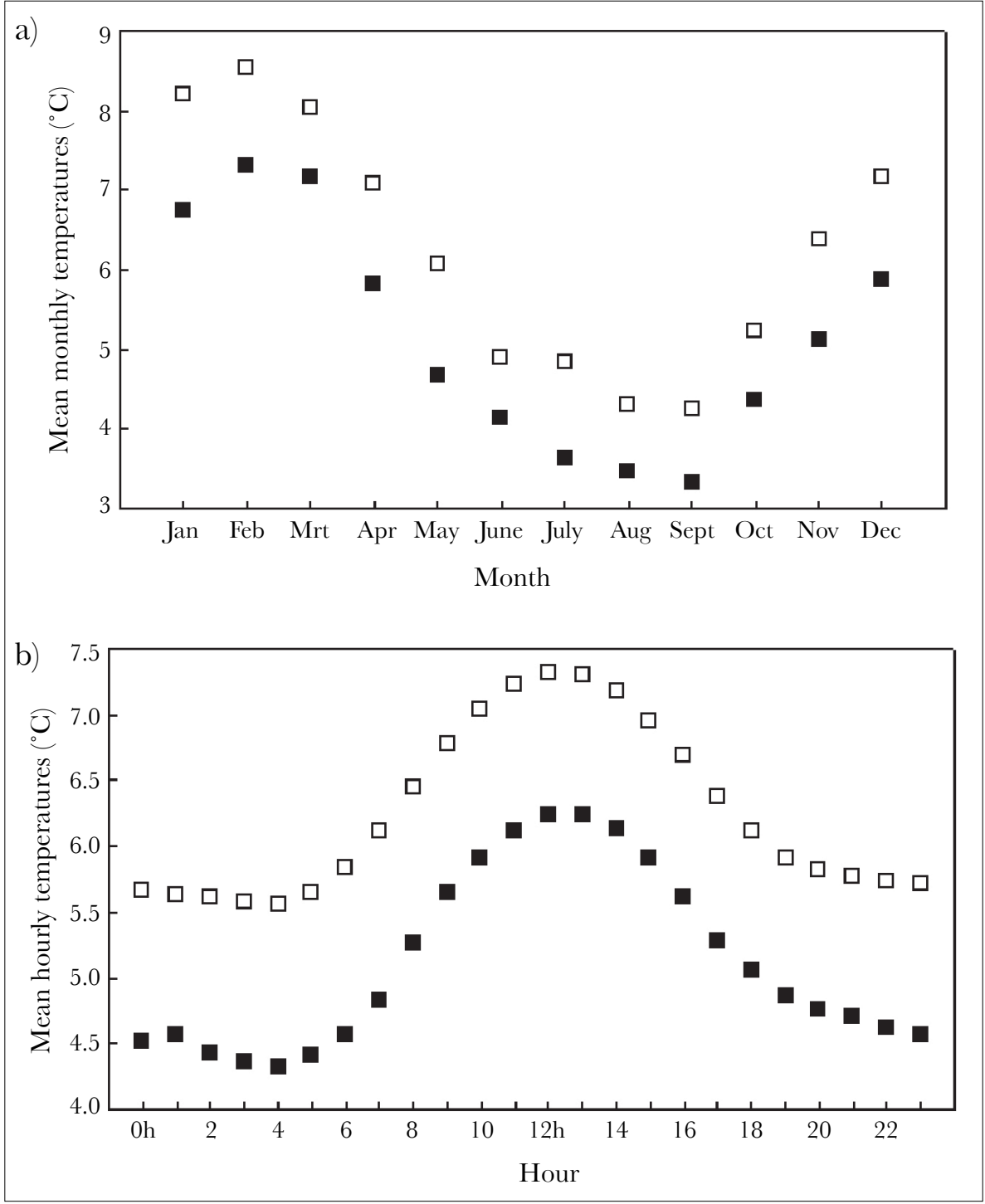

Figure 3.1 Temporal variation in air temperature (within Stevenson screen) on Marion Island. a) mean monthly temperatures, b) mean hourly temperatures. Filled symbols represent data from 1951-1961, empty symbols 1993-2003. Standard error bars excluded for clarity; for a) S.E. ranged between 0.026-0.032; for b) between 0.041-0.047. 
in the sub-Antarctic and around Antarctica) of appropriate data (see Venegas 2003). The ACW is an eastward-moving circumpolar bimodal anomaly in sea surface temperature, air pressure and sea ice extent (White \& Peterson 1996). However, the ACW was only clearly evident during the late 1980s and early 1990s (Venegas 2003; for Marion Island see Mélice et al. 2005), and even then had a weaker influence on sea surface temperatures in the Indian Ocean (including around Marion Island) than in the southern Pacific and Atlantic Oceans (Mélice et al. 2005).

Marion Island's climate is also distinguished by high precipitation and humidity, strong winds, and near complete cloud cover on most days - characteristics also exhibited by the other sub-Antarctic islands (French \& Smith 1985; Bergstrom \& Chown 1999). Marion Island receives precipitation as rainfall, snow, hail and mists, with some form of precipitation falling on most days and total annual precipitation averaging $1975 \mathrm{~mm}$ in the $1990 \mathrm{~s}$. Rainfall is the dominant form of precipitation at lower altitudes (Schulze 1971), with rainfall events of $\leq 5 \mathrm{~mm}$ and $>5 \mathrm{~mm}$ occurring on roughly $45 \%$ and $35 \%$ of days, respectively (le Roux \& McGeoch 2008). Graupel (a form of soft hail) and snow are common on the island, with the latter being far more common in winter months than in summer (Schulze 1971). Mists are possibly also an important form of precipitation, because they can lead to considerable condensation on some landforms and vegetation, especially when accompanied by strong winds (see e.g. Smith 1972). Precipitation is approximately evenly distributed throughout the year, although two minima can be distinguished; FebruaryMarch and October-November, with the latter receiving the least precipitation (Rouault et al. 2005; see Fig. 3.2a). Weak diurnal variation in precipitation exists on Marion Island, with a higher probability of precipitation around sunrise and sunset, but only in the summer months (Schulze 1971). Marion Island's high precipitation is matched by near complete cloud cover (on average $\geq 75 \%$ of sky covered by cloud). The persistent cloud results in the island only receiving $20 \%$ (winter) - 30\% (summer) of the possible solar radiation (Schulze 1971; Smith \& Steenkamp 1990). A significant proportion of the cloud observed on the eastern side of Marion Island could be of orographic origin with both low stratus and lenticularis clouds being commonly observed (Schulze 1971; see also Thost \& Allison 2005 for similar observations from Heard Island). Diurnal variation in cloud cover is not pronounced, with cloudier mornings in summer, but clearer mornings during winter months (Schulze 1971).

Relative humidity is high on the island (averaging 80\%), although short periods (usually $<5$ hours) of low $(<50 \%$, even dropping below 20\%) humidity can occur due to Föhn winds (Schulze 1971; Smith \& Steenkamp 1990). This occurs on the leeward side of the island as air moves over the central plateau. As the air moves up the windward mountain slope, it cools at the saturated adiabatic lapse rate (on average $0.43^{\circ} \mathrm{C}$ per $100 \mathrm{~m}$ elevation on Marion Island; Schulze 1971) and loses moisture (because its moisture-holding capacity declines with a decline in temperature). When the desiccated air then descends 
the leeward slope of the mountain, its temperature increases rapidly at the dry adiabatic lapse rate $\left(0.98^{\circ} \mathrm{C}\right.$ per $\left.100 \mathrm{~m}\right)$. Therefore, due to the differential rates of cooling and warming on the windward and leeward slopes (due to a change in the air's moisture content), the winds on the leeward side of the island can be much warmer and drier than the winds initially experienced on the windward slope (Schulze 1971; Bonan 2002). A Föhn wind can rapidly (within 30 minutes) raise air temperatures by $10^{\circ} \mathrm{C}$ and lower relative humidity by more than 20\% (Schulze 1971). Föhn winds are also important on other sub-Antarctic Islands (Fabricius 1957): e.g. Macquarie (Tweedie 2000), Heard (Thost \& Allison 2005) and Kerguelen Islands (Frenot et al. 1998; Frenot et al. 2001). On the latter island, these winds are thought to be responsible for the large ( $>2000 \mathrm{~mm}$ vs $800 \mathrm{~mm}$ ) precipitation difference between the eastern and the western sides of the island (Frenot et al. 1998).
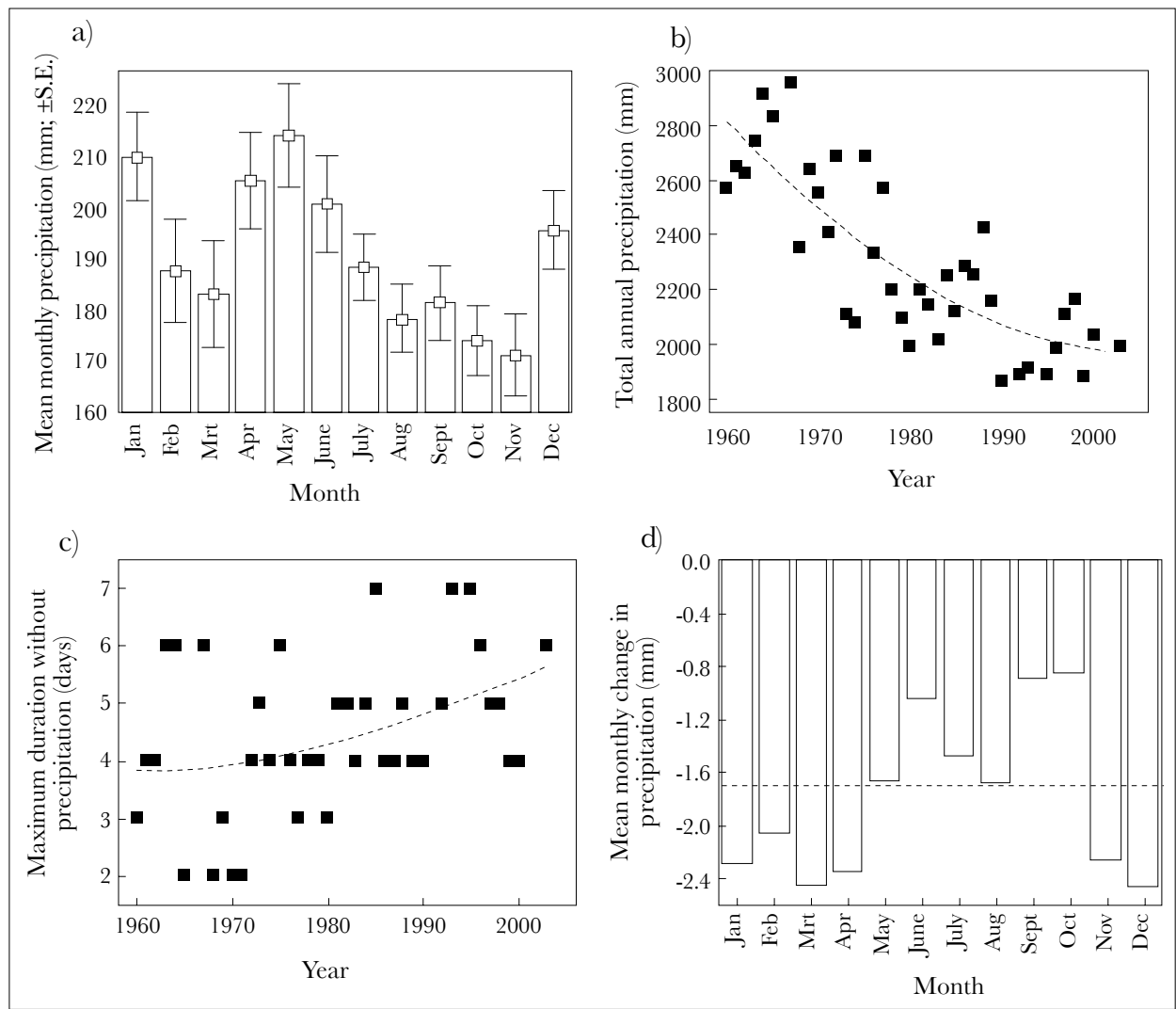

Figure 3.2 The annual and monthly distribution of, and changes in, precipitation on Marion Island, between 1960 and 2003. a) the mean monthly distribution of precipitation, b) the total annual precipitation, c) the duration of the maximum period without precipitation, d) the mean monthly change in precipitation. A negative exponentially-weighted curve (dashed line) has been fitted to the data in graphs b) and c). In d) the mean rate of change in precipitation is not significantly different from zero only in May, June, September and October. b) and c) with kind permission from Springer Science and Business Media (after minor modifications) from le Roux \& McGeoch (2008). 
Marion Island has a windy climate, in accordance with its position in the "roaring forties", experiencing gale force winds $\left(>15 \mathrm{~m} \mathrm{sec}^{-1}\right)$ on more than 100 days per year (Schulze 1971). Extended periods ( $>12$ hours) of continuous gales are not uncommon and calm periods are comparatively rare $(<10 \%$ of observations, Schulze 1971). Late summer winds are generally weaker (with disproportionately few gale strength winds) and have a stronger northerly component (Schulze 1971; Rouault et al. 2005). Diurnal variation in wind speed is much clearer, with faster wind speeds during the day than at night (Blake 1996), particularly in summer (Schulze 1971). The dominant wind direction recorded at the meteorological station is from the west, as expected from the island's location in a belt of strong, large-scale westerly atmospheric circulation, with north-westerlies being the strongest (averaging $>10 \mathrm{~m} \mathrm{sec}^{-1}$ ) and most common winds (60\% of observations; Schulze 1971; see also Rouault et al. 2005). Winds from south-west are a little weaker $\left(7 \mathrm{~m} \mathrm{sec}^{-1}\right)$ and the second most frequent (20\% of observations; Schulze 1971). By contrast, winds with an easterly component are rare $(<10 \%)$ and relatively weak (mean speeds of 3-6 $\mathrm{m} \mathrm{sec}^{-1}$; Schulze 1971). These winds differ not only in frequency of occurrence and speed, but also in temperature and moisture content, with winds with a northerly component being warmest (coming from the warmer sub-tropical zone) and carrying the most moisture (Schulze 1971; Hugo et al. 2004). By contrast, southerly winds comprise cold and dry Antarctic air (Schulze 1971; Smith \& Steenkamp 1990). Therefore, the climate of Marion Island is oceanic and, on average, cold, cloudy, wet and windy. However, an understanding of the circulation patterns around the island is required to recognize the factors responsible for short-term variation in weather, as well as longer-term changes in climate.

\subsection{Atmospheric circulation and the frontal nature of the weather}

In the Northern Hemisphere, the longitudinally-orientated continents provide a physical barrier to atmospheric and oceanic circulation. However, in the Southern Ocean strong eastward-flowing atmospheric and oceanic circumpolar circulation occurs due to the lack of such land masses at midand high latitudes of the Southern Hemisphere (Bonan 2002; Hall \& Visbeck 2002). The fastest winds in this eastward circulation occur within the southern polar jet stream, which is a relatively narrow air current near the tropospherestratosphere boundary which dominates mid-latitude circulation (Bonan 2002; Hall \& Visbeck 2002). The modal latitudinal position of the jet stream varies with time, and is related to the meridional (north-south) pressure and temperature gradients between the ocean-dominated mid-latitudes and the polar continental latitudes (Hartmann et al. 2000; Hall \& Visbeck 2002; although changes in mean ocean temperature could also play a role; Kushner et al. 2001). Even small changes in the latitudinal position of the southern polar jet stream have implications for large areas of the Southern Hemisphere, due to its effects on atmospheric and oceanic circulation (Fyfe \& Saenko 2005). For example, a southward shift in the modal position of the jet stream strengthens 
westerly winds at high Southern Hemisphere latitudes, but weakens those in the mid-latitudes (25-45 S; Hall \& Visbeck 2002; Gillett \& Thompson 2003; Rouault et al. 2005) with implications for air and ocean temperatures and currents (Hall \& Visbeck 2002).

Variation in the meridional pressure gradient, and therefore in the latitudinal position of the southern polar jet stream, is dominated by two processes: the Semi-Annual Oscillation (SAO) and the Southern Annular Mode (SAM). Both describe changes in the atmospheric mass (i.e. pressure anomalies) between mid- and high Southern Hemisphere latitudes, and have a similar spatial structure (Ainley et al. 2005; Rouault et al. 2005). The SAM and SAO can be considered distinct but related measures of the same phenomenon (i.e. the latitudinal gradient in pressure and temperature), with the SAO describing the magnitude of intra-annual variation and the SAM measuring interannual variation in the strength of the same gradient (Ainley et al. 2005; CLIVAR 2005; Raphael \& Holland 2006).

The SAO measures the magnitude of the half-yearly cycle in air pressure, temperature and westerly winds at mid- and high latitudes of the Southern Hemisphere. This biannual cycle is driven by an out of phase relationship between the annual temperature cycles between the ocean-dominated midlatitudes and the ice-dominated high latitudes (due to differences in heat storage, and therefore differential rates of spring warming and autumnal cooling, between Antarctica and the surrounding oceans; Van Loon 1967; Van den Broeke 1998). As a result a twice-yearly peak in the latitudinal temperature and pressure gradients exist (i.e. temperature and air pressure at mid-latitudes exceed the temperature and air pressure at high latitudes by greater than average amounts during spring and autumn), causing a poleward shift of both the jet stream and the circumpolar trough (a belt of low pressure and strong westerly winds encircling the globe at high southern latitudes) (Van Loon 1967). It is the strength of these temperature and pressure gradients that the SAO measures, with a common index being the difference between the zonally averaged (i.e. across all longitudes) 500-hPa temperatures at $50^{\circ}$ and $65^{\circ} \mathrm{S}$ (Van Loon 1967; Meehl et al. 1998). A weaker SAO therefore indicates a shallower latitudinal pressure and temperature gradient, and suggests less month-to-month variability in the latitudinal position of the jet stream than a stronger SAO (Meehl et al. 1998).

The SAM (also known as the Antarctic Annular Oscillation, AAO) appears to determine the largest proportion of the long-term climate variability in the Southern Hemisphere south of $20^{\circ} \mathrm{S}$ (Thompson \& Wallace 2000; Thompson $\&$ Solomon 2002). It measures the non-seasonal change in the atmospheric pressure between high and mid-latitudes of the Southern Hemisphere, and describes changes in the extent of the polar vortex (the large cyclonic system driving westerly circulation around the pole) and the associated changes in the strength of the westerly winds (Thompson \& Wallace 2000; Hall \& Visbeck 2002). A positive phase of the SAM is associated with a steeper latitudinal 
pressure gradient (e.g. measured between $40^{\circ}$ and $60^{\circ} \mathrm{S}$; Raphael \& Holland 2006), and therefore with the southward movement of the jet stream, stronger high latitude circumpolar circulation and faster westerly winds around continental Antarctica (i.e. stronger polar vortex), but weaker westerly circulation at mid-latitudes (Hall \& Visbeck 2002; Thompson \& Solomon 2002). In recent times, anthropogenic ozone depletion (cooling the troposphere over continental Antarctica) and increased greenhouse gas concentrations (raising tropospheric temperatures globally) have altered the strength and the seasonality of the latitudinal temperature and pressure gradient, affecting the strength of the SAM (Marshall et al. 2004). Changes in the SAM have been particularly evident during spring and summer months due to ozone loss being concentrated in spring (Hartmann et al. 2000; Marshall et al. 2004).

The presence of Rossby waves introduces additional variation to the position of the jet stream. Rossby waves (also known as long, planetary or westerly waves) are large-scale wave perturbations (wave lengths exceeding $2000 \mathrm{~km}$ ) in the westerly winds in the middle and upper troposphere, which can be observed as a meandering of the jet stream (Lutgens \& Tarbuck 1995; Tyson \& PrestonWhyte 2000; O'Hare et al. 2005). These waves cause regular distortions in the speed and direction of the air flow, with the degree of distortion varying through time (O'Hare et al. 2005). When the westerly air flow is smooth (i.e. westerly winds have a high zonal index, indicating that the air flow is predominantly zonal [west to east]), wind speeds are high and weather systems are rapidly transported eastwards. However, as the amplitude of the Rossby wave increases, westerly flow becomes slower and more distorted (i.e. a low zonal index state, indicating that meridional air flow [north-south] is increasing). Thus variation in the southern polar jet stream comprises both variability in its modal latitudinal position (affected by the latitudinal pressure and temperature gradients; measured by the SAO and the SAM) and variability in the distortion of its flow (due to Rossby waves).

Both the latitudinal position and the distortion of the jet stream are important for the weather of the mid-latitudes because the southern polar jet stream is a major source of both cyclones and anticyclones (transient atmospheric eddies) (Hall \& Visbeck 2002). The magnitude of Rossby waves within the jet stream influences the development of eddies, with eddy formation being most likely during low zonal index state flow (i.e. when the wave distortions are large and unstable enough that large cells of air can become detached from the jet stream) (O'Hare et al. 2005). During these periods of disrupted air flow, cyclones tend to form ahead of areas of low air pressure (troughs in the Rossby waves, i.e. zones of surface convergence of winds; Tyson \& Preston-Whyte 2000; O'Hare et al. 2005). In particular, the cyclones and anticyclones passing near Marion Island originate from the south Atlantic Ocean between $30^{\circ}$ and $40^{\circ} \mathrm{S}$ (Schulze 1971), one of the two foci for extra-tropical cyclogenesis in the Southern Hemisphere (Simmonds \& Keay 2000a). Both of these types of atmospheric circulation anomalies alter the prevailing westerly airflow, 
drawing warmer sub-tropical and/or cooler sub-Antarctic air masses over Marion Island (Smith \& Steenkamp 1990; Smith 2002).

By locally altering wind patterns, transient cyclones can dominate short-term weather variation on Marion Island if they pass close to the island. Cyclones (also known as depressions or low pressure systems) are characterized by clockwise circulation and the upward movement of the air column, and are therefore associated with cloudy weather. After their formation, cyclones move to the south-east, usually passing over, or to the west of Marion Island (Fig. 3.3). As a cyclone approaches the island, its associated clockwise winds draw warm sub-tropical air over the island, leading to a warm pre-cyclonic period (Smith \& Steenkamp 1990). The pre-cyclonic phase is also marked by an increased probability of precipitation and high cloud cover (since as the air moves upwards in the cyclone it cools and saturates, leading to cloud formation) as well as a strengthening of north-westerly winds. Once past Marion Island, a cyclone forces cooler, dry Antarctic air over the island, causing cold and clear conditions with weak south-westerly winds. The path followed by each cyclone, relative to Marion Island, determines the relative duration of pre- and postcyclonic conditions (Fig. 3.3), and therefore the effect the cyclone will have on the island's weather. A cyclone passing far south of the island has a longer but less intense pre-cyclonic period, followed by a shorter post-cyclonic period (Smith \& Steenkamp 1990; Smith 2002). In addition, when cyclone tracks are displaced southwards, the island is also affected more strongly by the distant, near-permanent South Indian Ocean anticyclone, which forces warmer winds with a more northerly component over Marion Island (Rouault et al. 2005). By contrast, when cyclones pass over the island, more intense pre- and postcyclonic conditions are experienced, with a roughly equal duration of each. As a result, with the passing of each cyclone (roughly 100 per year; Smith 2002), Marion Island experiences a recurrent switch from wet, warm pre-cyclonic days to cold, clear, dry post-cyclonic days, with the duration in each state determined by the cyclone's path (storm track) (Smith \& Steenkamp 1990).

By contrast with cyclones, anticyclones move eastward after formation, usually passing far north of Marion Island (Schulze 1971). They are high pressure systems (i.e. predominantly downward movement of air), surrounded by anticlockwise rotating winds. As a result, anticyclones are associated with clear weather (colder higher altitude air becomes relatively drier as it warms when moving to lower altitudes). The effect of these transient anticyclones on the island's weather is weak, except when storm tracks have shifted far southwards, bringing the cores of the anticyclones closer to Marion Island (Schulze 1971). By contrast, the near-permanent South Indian Ocean anticyclone, despite being centred far to the north-east of Marion Island, can have strong effect on the island's climate during periods of weak or infrequent cyclones (Rouault et al. 2005; see also Fig. 3.3). Thus, both cyclones and anticyclones have considerable effects on Marion Island's climate, depending on the proximity of storm tracks to the island. 


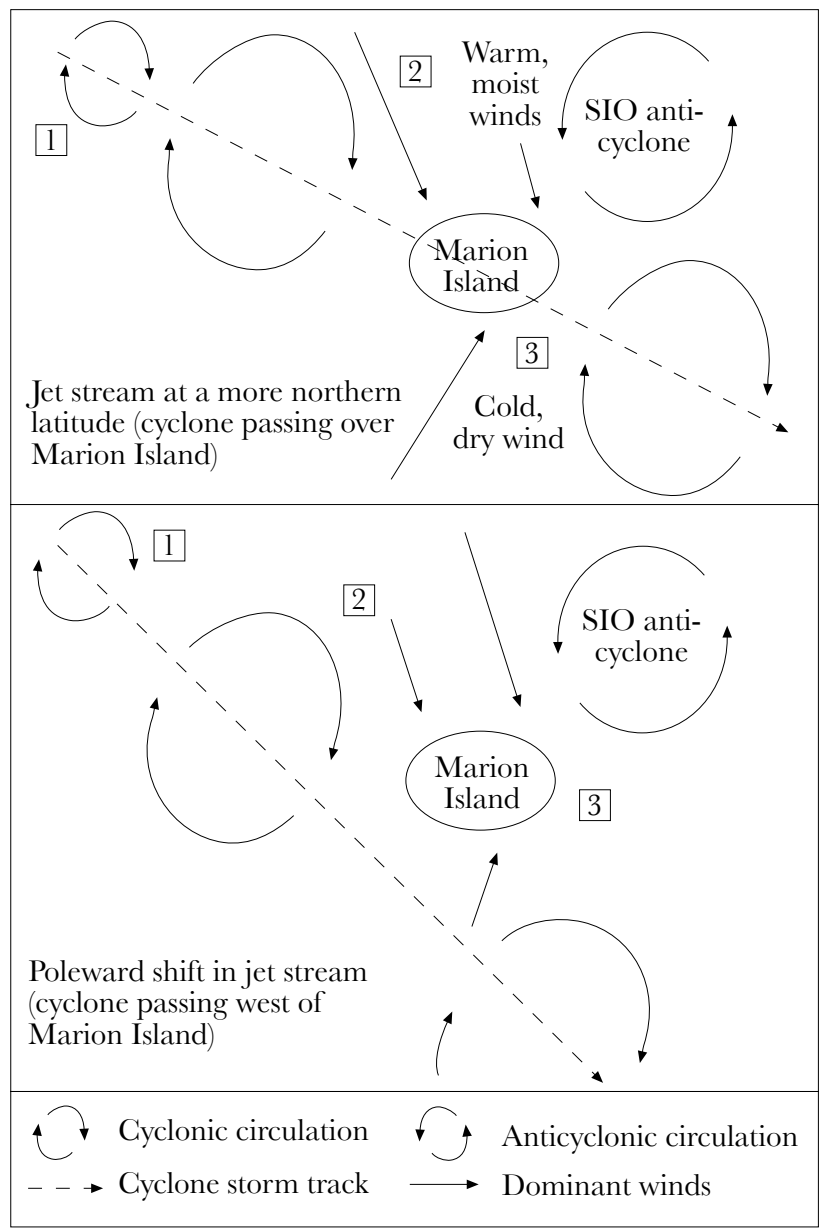

Figure 3.3 A comparison of the wind patterns generated by different cyclone storm tracks. The numbers indicate the eastward progression of the cyclones. The length of the straight arrows indicate the relative changes in wind strength between the two panels. SIO anticyclone - South Indian Ocean anticyclone.

Top: a more northerly storm track (i.e. during winter) causes an approximately equal duration of pre- (2) and post-cyclonic conditions (3). Strong north-westerly (2) and south-westerly (3) winds are experienced. Bottom: a poleward shift in storm tracks causes longer but less intense pre-cyclonic conditions (2). The duration of post-cyclonic conditions is shorter (3). The SIO anticyclone has a stronger influence, increasing the northerly component of winds, bringing warm, moist sub-tropical air over the island. If a cyclone passes north of the island, the opposite pattern would occur, with the duration of post-cyclonic conditions exceeding that of the pre-cyclonic conditions. 
The position of the southern polar jet stream strongly determines the position of storm tracks (Kushner et al. 2001; Hall \& Visbeck 2002). Therefore, a southward shift of the jet stream leads to a poleward shift in storm tracks, altering the relative effects of the passing cyclones and anticyclones on Marion Island's weather (Rouault et al. 2005). This effect is evident in the seasonal variation in storm tracks past Marion Island (storm tracks pass further south in summer months, following the poleward shift of the mean pressure distribution; Schulze 1971). The correlation between storm track position and jet stream latitude is also known over larger temporal and spatial scales in the Southern Hemisphere (Kushner et al. 2001). Marion Island, along with Heard Island, lies close to the mean cyclone storm track, and therefore their climates probably have a stronger frontal nature than some of the other subAntarctic islands (e.g. Macquarie Island lies in a zone of cyclone deterioration, while Bouvet and the Crozet Islands are located relatively far from the passage of most storm tracks; see Simmonds \& Keay 2000a). Thus, despite broad similarity in climate across the sub-Antarctic, the proximity of each island to storm tracks does cause some differences in their climates. While the latitude at which these eddies are formed is determined by the latitudinal position of the jet stream, the subsequent movement of an eddy is also strongly affected by the Rossby waves propagating along the jet stream (Lutgens \& Tarbuck 1995; O'Hare et al. 2005). As a result, both the latitudinal position of the jet stream and the amplitude of Rossby waves within the jet stream are important for the formation and subsequent movement of transient eddies.

Therefore, the passage (and number) of passing atmospheric eddies and the position and state of the jet stream strongly affect Marion Island's climate, with the short-term alternation between warm-wet and cold-clear weather being determined by the passage of individual frontal systems. Longer-term climate is affected by the broader-scale circulation patterns that determine the position of the southern polar jet stream and the number, intensity and mean position of the frontal systems that the jet stream spawns.

\subsection{Spatial variation in climate on Marion Island}

On numerous occasions I found it necessary to cover the final fifty metres to the summit of a volcano on hands and knees for fear of being blown off, while on my return to the meteorological station have found that only a gentle breeze had been recorded. (Huntley 1970)

Spatial variation in Marion Island's climate is widely recognized (e.g. Schulze 1971; Chown \& Avenant 1992; Blake 1996), but is as yet still not completely understood (a problem not unique to Marion Island; see e.g. Thost \& Allison 2005). Data from the island's meteorological station describes the climate inside a Stevenson screen located near the coast on the eastern side of the island (Schulze 1971). However, since weather conditions vary with topography, aspect, altitude and recording height (Bonan 2002; see also e.g. Beggs et al. 2004), considerable variation in climate occurs across the island. 
The nature of climatic differences between the different sides of the island have long been speculated about (e.g. Schulze 1971; le Roux 2004; Rouault et al. 2005), but little comparable meteorological data exist with which to test these ideas. Due to the prevalence of westerly winds, it has been hypothesized that climate differs most between the eastern (predominantly leeward) and western (windward) sectors of the island. The western sector has been suggested to have stronger and less variable winds, higher humidity and rainfall, and less variable temperatures (Rouault et al. 2005; see also Gremmen 1981). Additionally, the west should rarely experience Föhn winds (which are not uncommon on the east), and could have a different pattern of cloud cover (Schulze 1971; see also Thost \& Allison 2005 for Heard Island). The only available data suggest that, indeed, temperatures are less variable on the western side of the island relative to those on the east, with warmer temperatures during winter and cooler temperatures during summer (temperatures in Azorella selago cushions on both sides of the island; Nyakatya \& McGeoch 2008; see Fig. 10.7a in McGeoch et al. 2008). Observations from other sub-Antarctic islands suggest that climate can, in some situations and for some climate parameters, differ greatly between eastern and western sectors. For example, annual precipitation differs more than four-fold between the eastern and western parts of Kerguelen Island (due to a pronounced Föhn effect; Frenot et al. 1998). On Heard Island, large differences in climate are observed between the eastern and western sectors, with the eastern slopes experiencing faster and more variable winds (due to the formation of Von Karman vortices in the lee of the island; Beggs et al. 2004), and lower cloud cover and precipitation (Hughes 1987). By contrast, temperature does not differ between the eastern and the western sides of Macquarie and Kerguelen Islands (Frenot et al. 1998; Davies \& Melbourne 1999; wind speed also does not differ between the eastern and western sectors on Macquarie Island; Davies \& Melbourne 1999). Thus on Marion Island significant topographically-generated differences in climate are likely between the eastern and western sides of the island, although these require more extensive documentation.

Altitudinal variation in climate on Marion Island has also been poorly explored (see Fig. 10.6 in McGeoch et al. 2008 for some observed and hypothesized altitudinal gradients). Mean altitudinal lapse rates of $4.5^{\circ} \mathrm{C}$ per $1000 \mathrm{~m}$ in winter and $4.0^{\circ} \mathrm{C}$ in summer have been calculated from radiosonde data collected on the island (Schulze 1971), with surface data showing slightly higher rates (Boelhouwers et al. 2008). Research by Blake (1996) confirmed that higher altitudes are both cooler and windier, with higher cloud cover and a greater daily temperature range than lower elevations. In agreement with Blake's (1996) speculation, the decline in temperature appears to be mainly due to daily minimum temperatures dropping with increasing altitude, while daily thermal maxima are independent of elevation (soil temperatures: Slabber \& Chown 2004; see also Boelhouwers et al. 2003 for air and soil temperatures). This difference in the behaviour of the thermal minima and maxima explains the wider temperature range at higher elevations (also observed 
on Heard Island; Allison \& Keage 1986; but not observed for within-Azorella selago cushion temperatures on Marion Island across an altitudinal range of +400 m; Nyakatya \& McGeoch 2008). Interestingly, this pattern can sometimes be reversed during winter at high altitudes, where snow cover strongly buffers temperatures, causing a very narrow daily temperature range (Blake 1996, but see also Boelhouwers et al. 2008). Increasing wind speed with altitude is another consistent trend observed among the sub-Antarctic islands (Blake 1996; Davies \& Melbourne 1999; Beggs et al. 2004). Altitudinal trends for precipitation on Marion Island are less clear than for other weather parameters and suggested that maximum precipitation occurs at mid-altitudes, although this could be an artifact of topographical differences between observation sites (Blake 1996). On Macquarie Island, precipitation varies independently of altitude, but relative humidity and rates of evapotranspiration both increase with elevation (Tweedie 2000). Therefore, on that island, the rate of moisture loss (via evaporation from the soil surface and transpiration by plants) is fastest at high altitudes, possibly due to higher wind speeds, despite the air moisture increasing with elevation. Wind direction also differs between altitudes on Marion Island, although this is probably due to topographical differences between sites (Blake 1996; see also Chown \& Avenant 1992). These results, therefore, indicate that distant locations on the island can experience rather different weather, but again that more comprehensive climate recording and modelling is needed for the island.

Even sites separated by smaller distances can have distinctly different weather conditions. Indeed, at these finer-scales, microclimate and the climate recorded within a Stevenson screen ("macroclimate") can be decoupled, with microclimatic conditions varying nearly independently of macroclimate. As a result, steep temperature, moisture and wind gradients can be observed over very short distances. For example, temperatures within $A$. selago cushions and Poa cookii tillers can be $1-4^{\circ} \mathrm{C}$ warmer than those recorded inside a nearby Stevenson screen (Chown \& Crafford 1992; see also Fig. 10.2 in McGeoch et al. 2008). Similarly, the thermal environment within mouse burrows in Blechnum penna-marina and $A$. selago is buffered relative to ambient air temperature (Avenant \& Smith 2003). Due to the highly oceanic nature of Marion Island's climate, these variations in microclimate are important determinants of community properties (since macroclimate differs relatively little between sites; Smith \& French 1988). For example, despite little above-ground vegetation on higher altitude scoria cones, within the shelter created by the blocky substrate a "hypolithic" community of mosses, liverworts and invertebrates survives (Van Zinderen Bakker 1978).

The difference between macro- and microclimate varies between microhabitats, with the degree of shelter from the wind and the amount of solar insolation received being the most important determinants of microclimate (Chown \& Crafford 1992). Indeed, microclimate temperature is most decoupled from macroclimate where a habitat is sheltered from the wind, with the difference 
exaggerated on clear, cloudless days (Van Zinderen Bakker 1978; Smith 1992). Slope aspect also affects microclimate, with north-facing slopes warming more than south-facing slopes (Huntley 1971). Similarly, the northern aspects of A. selago cushions may be warmer than their southern portions, with wind direction also affecting the microclimate in different sectors of a single cushion (Hugo et al. 2004; McGeoch et al. 2008). Thus the climate on Marion Island shows considerable spatial variation, across both large and small scales.

\subsection{Contemporary changes in climate}

Over the last half century Marion Island has experienced rapid changes in climate, with warming taking place at more than twice the mean global rate. The island may thus be a true sentinel for future changes in climate (Bergstrom \& Chown 1999). Relative to the island's diurnal and seasonal climate variability, these changes are considerable (Smith \& Steenkamp 1990), and have already had measurable impacts on the physical (lower peat moisture levels; Chown \& Smith 1993; reduction in the size of the ice cap, and the disappearance of a permanent snow line; Sumner et al. 2004) and biotic features (higher Uncinia compacta cover; Chown \& Smith 1993; changes in productivity; Pakhomov et al. 2004; see also le Roux \& McGeoch 2008) of the Prince Edward Islands. In addition, if current climate trends continue, further ecological changes are predicted (e.g. increased house mouse abundance, with negative effects on nutrient cycling and the abundance of macro-invertebrates and Lesser Sheathbills; Smith \& Steenkamp 1990; Chown \& Smith 1993; Huyser et al. 2000; increased stem senescence in A. selago; le Roux et al. 2005; changes in the structure of the micro-invertebrate community associated with A. selago; McGeoch et al. 2006; Chown et al. 2007).

The air and sea (surface and sub-surface) temperatures at mid-latitudes of the Southern Ocean have warmed significantly between the 1950s and 2000s, although at a spatially and temporally variable rate. The most pronounced changes in sea temperatures have occurred within the Antarctic Circumpolar Current, with sub-surface sea temperatures rising by $0.17^{\circ} \mathrm{C}$ between the $1950 \mathrm{~s}$ and 1980s (Gille 2002). Around Marion Island greater warming occurred with sea surface temperatures increasing by $1.4^{\circ} \mathrm{C}$ between 1949 and 1999 (Mélice et al. 2003). Matching the increased sea temperatures, air temperature on Marion Island increased by $1.2^{\circ} \mathrm{C}$ over the same period (Fig. 3.4a; Smith 2002; le Roux \& McGeoch 2008). This high rate of warming is relatively consistent among the sub-Antarctic islands (Frenot et al. 1997; Tweedie \& Bergstrom 2000; Weimerskirch et al. 2003; Thost \& Allison 2005), and is comparable to the warming experienced on the Antarctic peninsula over the same period (Vaughan et al. 2003), suggesting a regional change in climate, rather than, for example, a change in distant ocean processes (Reason \& Lutjeharms 2000). On Marion Island, daily maximum and minimum temperatures have risen at a similar rate to mean temperatures, resulting in a roughly constant daily temperature range (le Roux \& McGeoch 2008). This is an unusual pattern 
because globally, thermal minima are increasing faster than maxima, leading to a narrowing of the daily temperature range (IPCC 2001). Annual maxima and minima on Marion Island have also risen, with the five warmest years on record in the last decade (1996-2000; le Roux \& McGeoch 2008; see also Smith 2002). In addition, Marion Island's thermal regime has become less variable over this period (despite daily temperature ranges not decreasing), with decreased day-to-day variability in temperatures (Fig. 3.4b; le Roux \& McGeoch 2008). Ocean temperatures have risen significantly in all months, with minimum warming in the mid-winter months (June and July; Rouault et al. 2005). By contrast, there has been a clear seasonal pattern to increasing air temperatures, with the greatest warming in the late summer months (Fig. 3.4c; Smith 2002; Rouault et al. 2005).

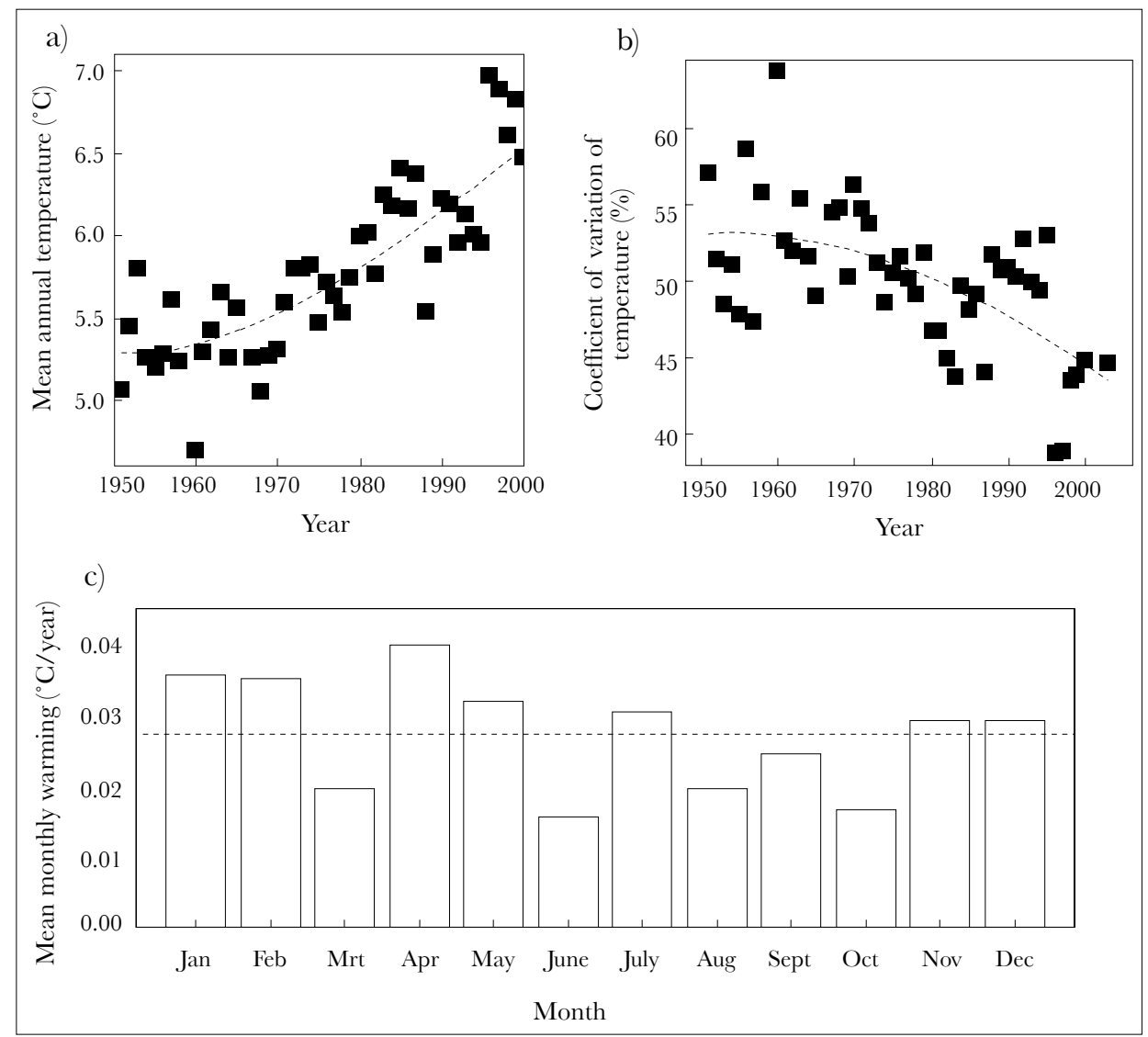

Figure 3.4 Changes in temperature on Marion Island, between 1951 and 2003. a) mean annual temperature, b) annual coefficient of variation for $08 \mathrm{~h} 00$ temperatures, c) mean warming rate split by month (the warming trend was significant in all months, except June). A negative exponentiallyweighted curve (dashed line) has been fitted to the data in a) and b). The dotted line in c) represents the mean monthly rate of warming. a) and b) with kind permission from Springer Science and Business Media (after minor modifications) from le Roux \& McGeoch (2008). 
Over the same period Marion Island's precipitation has decreased significantly (Fig. 3.2b), in contrast with other sub-Antarctic islands (e.g. no trend on Kerguelen Island; Frenot et al. 1997; increased precipitation since the 1970s on Macquarie Island; Kirkpatrick \& Scott 2002). The decline in precipitation is a result of both fewer and smaller precipitation events (le Roux \& McGeoch 2008). The mean and maximum duration between precipitation events have also increased (Fig. 3.2c; le Roux \& McGeoch 2008; see also Rouault et al. 2005). These changes therefore represent a considerable shift in the island's precipitation patterns (i.e. the timing, frequency and size of events). The reduction in precipitation has been most pronounced between November and April (Fig. 3.2d), although the increase in the number of days without precipitation has been more uniform throughout the year (increases of up to six days per month; Rouault et al. 2005; see also Smith 2002; le Roux \& McGeoch 2008). Mean cloud cover has decreased over the last 50 years, although it peaked in the 1970s before declining to current levels (Fig. 3.5a). These changes in precipitation and cloud cover, in unison with the warmer temperatures, appear to have driven the loss of Marion Island's permanent snowline, which in the 1960 s occurred down to $500-850 \mathrm{~m}$ a.s.l. (Huntley 1970; Sumner et al. 2004). These trends are also thought to be responsible for the melting of much of Marion Island's ice plateau (Sumner et al. 2004), as well as similar changes in the ice caps and glaciers on Heard and Kerguelen Islands (Allison \& Keage 1986; Frenot et al. 1993; Budd 2000).

Analyses of wind data suggest that wind patterns on Marion Island have also changed, with an increasing northerly component. Since the 1960s, mean wind direction has shifted northward during late summer and autumn, with

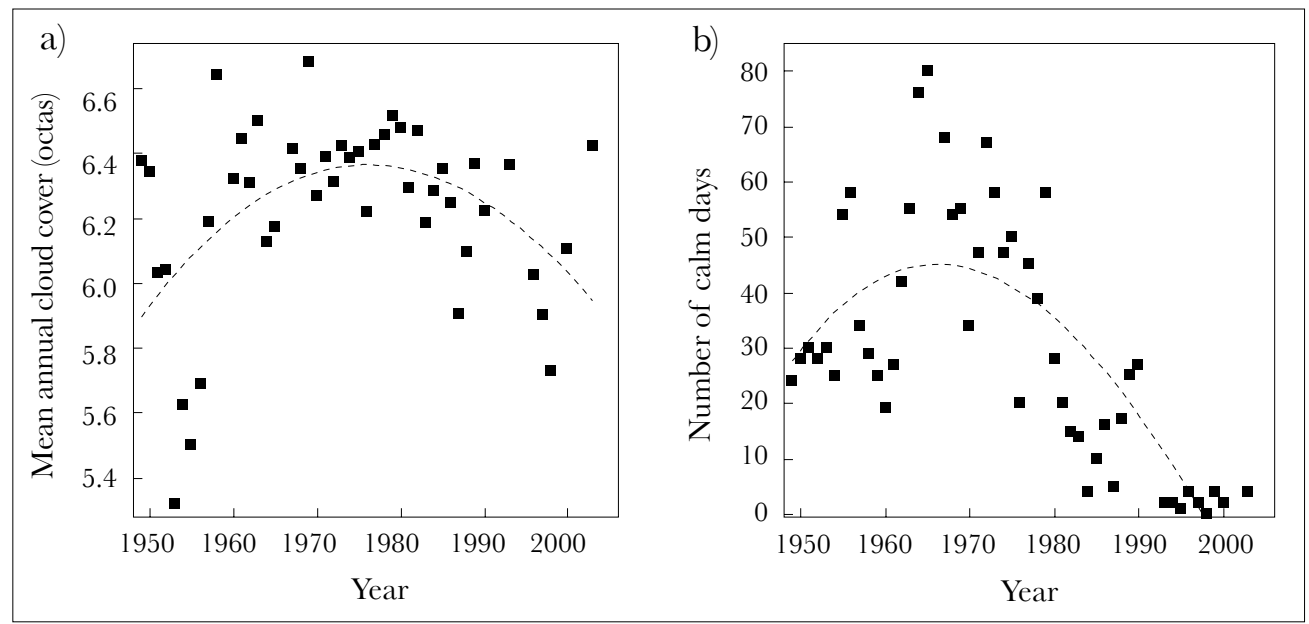

Figure 3.5 Changes in cloud cover and wind speed on Marion Island, between 1949 and 2003. a) mean cloud cover (08h00 observations), b) number of wind still measurements (08h00 observations). A negative exponentiallyweighted curve (dashed line) has been fitted to the data in both graphs. With kind permission from Springer Science and Business Media (after minor modifications) from le Roux \& McGeoch (2008). 
shifts in some months exceeding $20^{\circ}$ (based on NCEP reanalysis climate data; Rouault et al. 2005). Wind speeds on Marion Island increased during the 1970s, but decreased again after peaking in the mid-1980s (le Roux \& McGeoch 2008). However, comparing wind speed between 1960-70 and 1980-2000 still shows higher meridional wind speed in the latter period (but no difference for zonal (east-west) winds; Rouault et al. 2005). Thus, over the last 50 years, northerly winds have become stronger and more frequent, while westerly winds have become less common (although not weaker). Despite the peak in wind speed in the 1980s, variability in wind speed declined throughout the period, possibly due to the considerable drop in the number of calm periods (Fig. 3.5b). Therefore, the recent changes in Marion Island's wind patterns differ between parameters, with peak wind speed in the 1980s, maximum calm days in the 1960s, declining wind variability since the $1950 \mathrm{~s}$, and different trends for meridional and zonal winds. These trends partly agree with the hemisphere-wide trends for faster westerly winds around $60^{\circ} \mathrm{S}$, and increasing northerly components to winds around $40^{\circ} \mathrm{S}$ (Kushner et al. 2001; Hall \& Visbeck 2002).

Overall, these changes have lead to non-linear changes in Marion Island's climate system as a whole. Over the last five decades, Marion Island's climate has become consistently warmer (with lower thermal variability) and drier (with increased variability in precipitation), with winds which are more frequent (fewer calm days) and less variable (Fig. 3.6; le Roux \& McGeoch 2008). These climate trends have occurred roughly concurrently, with approximately linear trends over time, and comprise a trend complex (i.e. a group of climate parameters with corresponding trends over time; Huth \& Pokorná 2005). However, over the same period, changes in wind speed have been distinctly non-linear, and represent a second trend complex. Therefore, climate change on Marion Island is not a simple process of all variables responding at the same rate to the same forcing, but rather an example of where trends in climate parameters are decoupled (e.g. roughly linear changes in temperature, precipitation and wind direction, but non-linear (parabolic) trends in wind speed). This is especially pronounced since wind variables usually form a single trend complex, with concurrent changes in wind speed and direction usually observed (Huth \& Pokorná 2005).

\subsection{Mechanisms driving sub-Antarctic climate change}

The coincident increases in temperature across the sub-Antarctic since the 1960s suggest that shifts in large-scale circulation patterns are responsible for recent changes in climate. Specifically, changes in regional atmospheric circulation appear to be responsible for the changes in Marion Island's climate (Reason \& Lutjeharms 2000). In particular, the increased influence of the South Indian Ocean anticyclone on air and ocean currents in the mid-southern latitudes around Marion Island seems to be the most important recent change to regional circulation (Rouault et al. 2005). While the strength and position 
of the South Indian Ocean anticyclone has not changed over this period, its influence on the climate of Marion Island has increased during recent years due to the weaker influence of transient cyclones closer to the island (e.g. see Fig. 3.3). Thus, due to the weakening effect of transient cyclones in recent years, the South Indian Ocean anticyclone has increased the advection of warmer tropical water into the mid-latitudes of the sub-Antarctic by strengthening the Agulhas current (Reason \& Lutjeharms 2000; Rouault et al. 2005). This could be responsible for the apparent southward shift of the sub-Antarctic front, resulting in warmer oceanic waters in the vicinity of Marion Island (Pakhomov \& Chown 2003; see also Hall \& Visbeck 2002).

The weakening of the effect of passing cyclones on Marion Island's climate appears to be due to a reduction in the number of sub-Antarctic cyclones as well as a poleward shift in mean cyclone storm track position. Between 1970 and 1997, the number of cyclones in the sub-Antarctic declined by $10 \%$ (Fyfe 2003), probably as a result of the warming of the Southern Hemisphere (Simmonds \& Keay 2000b). Changes in the position of cyclone storm tracks

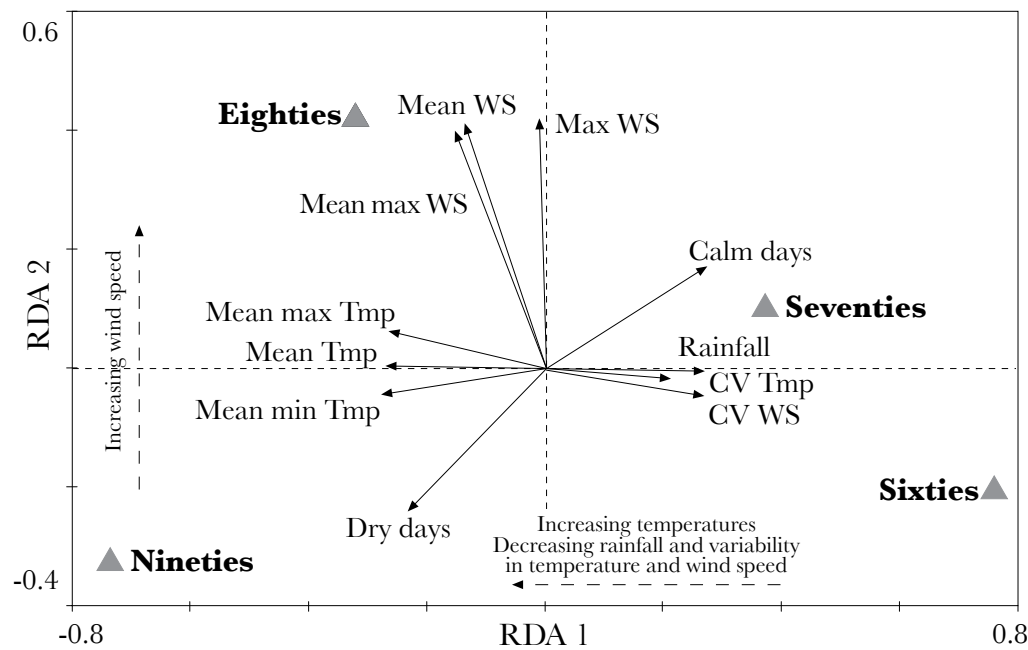

Figure 3.6 Ordination (Redundancy analysis) of annual climate (excluding 1950s due to lack of precipitation data for that period; axes explain $33.2+$ $8.6 \%$ of annual variability) showing the centroid for each decade (triangles; i.e. the average climate for each decade) and fitted climate variables (arrows). The distance between centroids approximates the dissimilarity in climate between decades. Climate arrows pointing in the direction of a particular centroid indicate that the specified climate parameter had the highest mean value during that decade, with arrow length equal to the relative contribution of that climate variable to the ordination subspace definition. Dashed arrows indicate hypothesized gradients across the ordination space. CV - coefficient of variation, Dry days - number of days without precipitation, Max - maximum, Min - minimum, Tmp - temperature, WS - wind speed. With kind permission from Springer Science and Business Media (after minor modifications) from le Roux \& McGeoch (2008). 
have also had an effect on the current climate trends. Indeed, a pronounced southward shift in storm tracks is thought to have accompanied the poleward shift of the southern polar jet stream in recent years (indicated by increasingly positive values of the SAM; Kushner et al. 2001; Rouault et al. 2005). This suggests that anthropogenically-driven stratospheric ozone depletion (cooling the Antarctic) and increased greenhouse gas concentrations, causing steeper latitudinal temperature and pressure gradients (i.e. increasing the SAM and shifting the jet stream polewards), are at least partly responsible for changes in the storm track positions (Thompson \& Solomon 2002; Marshall et al. 2004; Shindell \& Schmidt 2004), and therefore for increasing the influence of the South Indian Ocean anticyclone on Marion Island's climate (Rouault et al. 2005).

The recent positive trend in the strength of the SAM also indicates the possibility of the weakening of Rossby waves in the southern polar jet stream. Indeed, since the 1980s a negative relationship has been observed in the Northern Hemisphere between the strength of Rossby waves and the magnitude of the Northern Annual Mode (the Northern Hemisphere equivalent of the SAM; Hartmann et al. 2000). Furthermore, the stronger high latitude winds associated with the positive phase of the SAM (and the stronger polar vortex) could cause Rossby waves to be deflected to lower latitudes (Hartmann et al. 2000; Hu \& Tung 2003; see also results of Simmonds \& Keay 2000b). This suggests that the conditions driving a stronger SAM are also probably influencing the amplitude and position of Rossby waves in the jet stream, with possible consequences for the formation and subsequent movement of cyclones and anticyclones.

The southward shift of the jet stream could also be influencing sea surface temperatures directly. The weaker and warmer sub-Antarctic winds (associated with the positive phase of the SAM) reduce evaporative heat loss from midlatitudes in the Southern Ocean, causing a rise in ocean surface temperatures (Hall \& Visbeck 2002; Rouault et al. 2005). Interestingly, over the same period the SAO has weakened considerably, as a result of uneven warming throughout the year at both mid- and high southern latitudes (Meehl et al. 1998; Simmonds \& Jones 1998). This suggests that intra-annual variability in jet stream position and cyclone activity has decreased since the 1970s (Meehl et al. 1998). Indeed, both the increasing strength of the SAM and the decreasing magnitude of the SAO are strongly correlated with the climate trends on Marion Island (Rouault et al. 2005), although the mechanism by which a weakening SAO could have caused the long-term trends observed in the island's climate is still unclear. Thus, changes in the frequency, intensity and passage of cyclones in the sub-Antarctic, driven by stratospheric ozone loss and global warming, appear chiefly responsible for the observed changes in climate on Marion Island (Smith \& Steenkamp 1990; Rouault et al. 2005).

Similar to the SAM, another interannual, large-scale circulation pattern, the El Niño Southern Oscillation (ENSO), has also increased in intensity and frequency over the same period (IPCC 2001). ENSO affects both tropical and Antarctic regions (e.g. South Pacific Ocean, and the Ross, Amundsen and 
Bellingshausen seas west of the Antarctic Peninsula; Turner 2004; Rouault et al. 2005), but appears to have little influence on Marion Island's climate (see le Roux \& McGeoch 2008). Interestingly, though, it has been speculated that unusual bird breeding success levels in 1997/98 (including the highest success rates on record for Marion Island for the Northern and Southern Giant Petrels, but low success rates for the Gentoo Penguin and Crozet Shag) could be related to a particularly strong El Niño that year (Crawford et al. 2003, see also Cooper \& Lutjeharms 1992). If bird breeding on Marion Island in $1997 / 98$ was really affected by El Niño, this suggests that while El Niño has little effect on the climate experienced on Marion Island, it may have a strong influence in areas which are important for the species' prey (especially since there was a sharp distinction in performance between near-shore and distantfeeders; Crawford et al. 2003).

\subsection{Future climate trends}

Coarse-scale climate models suggest further warming across the globe for at least the next 200 years (Meehl et al. 2005). The southern Indian Ocean is predicted to warm by a further $1-3^{\circ} \mathrm{C}$ by $2070-2100$, suggesting that air temperatures on Marion Island are likely to increase by a similar magnitude (IPCC 2001). Indeed, this figure fits with the current rate of warming on the island, but is considerably larger than estimates for Macquarie Island $\left(+0.1^{\circ} \mathrm{C}\right.$ per decade between 1998 and 2030, based on ARIMA analyses; Tweedie \& Bergstrom 2000). Fewer predictions have been made regarding changes in precipitation, with the current consensus being that changes in precipitation will be spatially variable (IPCC 2001), in agreement with the dissimilarity of current precipitation trends across the sub-Antarctic islands. However, if current climate trends continue on Marion Island, moisture availability could decline due to lower precipitation and/or higher temperatures driving faster evaporation.

Continued increases in greenhouse gas concentrations are predicted to not only cause warmer temperatures, but also further southward shifts in the southern polar jet stream (i.e. more positive SAM values) and of the northern boundary of the Antarctic Circumpolar Current (Kushner et al. 2001; Fyfe \& Saenko 2005). This suggests stronger atmospheric and oceanic circulation near the Antarctic continent, but weaker circulation in the sub-Antarctic (Hall \& Visbeck 2002; Gillett \& Thompson 2003). As a result, warming may be matched by slower winds (with a stronger northerly component) on Marion Island. Furthermore, the number of cyclones in the sub-Antarctic is predicted to decline by a further $30 \%$ by 2100 , in response to the warming of the Southern Hemisphere (Fyfe 2003). As a result, the climate of Marion Island can be expected to be more strongly affected by the South Indian Ocean anticyclone in the future, suggesting warmer temperatures and weaker winds on the island.

These scenarios, however, focus only on the effects of increased greenhouse gas concentrations, ignoring the important effects of the ozone layer on 
atmospheric dynamics. In the mid-1990s, the rate of stratospheric ozone loss levelled off, marking the start of the recovery of the layer (Yang et al. 2005). This could have a variety of effects on Marion Island's climate, because higher concentrations of stratospheric ozone will intercept more ultra-violet radiation, leading to a warming of the upper, and then lower, atmosphere above Antarctica. The concurrent replenishment of the ozone layer and the continued increase in greenhouse gas concentration are predicted to act antagonistically on circulation (i.e. having little effect on wind patterns; Shindell \& Schmidt 2004), but to have a synergistic effect on raising temperatures (Hartmann et al. 2000; Shindell \& Schmidt 2004). Warming of the Antarctic will also weaken the latitudinal temperature gradient between the tropics and the polar regions, probably causing a northwards shift in the position of the jet stream, with the SAM returning to a more neutral phase. As a result, cyclone storm tracks could pass closer to Marion Island again, with associated changes in temperature, precipitation, cloud and wind patterns on the island. Thus, while the rate of warming at high latitudes in the Southern Hemisphere is likely to increase, associated changes in the position of storm tracks could result in Marion Island actually becoming cooler and wetter again, with strengthened westerly and weakened northerly winds. Thus, Marion Island's climate could conceivably shift to either being cooler, wetter and windier (i.e. more strongly affected by passing cyclones) or, as supported by current trends, to warmer and drier conditions (no change or decreasing effects of cyclones). The outcome is likely to depend on the balance of relative effects of warming temperatures, declining cyclone abundance, and changing storm tracks. Either way, the climate of Marion Island is likely to continue to change rapidly over the next century, remaining an important indicator of climate in the Southern Ocean, and highlighting the importance of continued quality weather monitoring on the island. Finally, if we are to understand the consequences of such change to the island itself, far more detailed and comprehensive meteorological readings are needed at both fine and island-wide scales because of the island's topographic complexity.

\subsection{Acknowledgements}

The South African Weather Service and its personnel are thanked for collecting and providing weather recordings from Marion Island. M.A. McGeoch, M.J. Nyakatya, V.R. Smith and S.L. Chown are thanked for advice and discussion.

\subsection{References}

Ainley, D.G., Glarke, E.D., Arrigo, K.,

Fraser, W.R., Kato, A., Barton, K.J., et al. 2005. Decadal-scale changes in the climate and biota of the Pacific sector of the Southern Ocean, 1950s to the 1990s. Antarctic Science 17, 171-182.
Allison, I.F. \& Keage, P.L. 1986. Recent changes in the glaciers of Heard Island. Polar Record 23, 255-271. 
Ansorge, I.J. \& Lutjeharms, J.R.E. 2000. Twenty-five years of physical oceanographic research at the Prince Edward Islands. South African Fournal of Science 96, 557-565.

Avenant, N.L. \& Smith, V.R. 2003. The microenvironment of house mice on Marion Island (sub-Antarctic). Polar Biology 26, 129-141.

Beggs, P.J., Selkirk, P.M. \& Kingdom, D.L. 2004. Identification of Von Karman vortices in the surface winds of Heard Island. Boundary-layer Meteorology 113, 287-297.

Bergstrom, D.M. \& Chown, S.L. 1999. Life at the front: history, ecology and change on Southern Ocean islands. Trends in Ecology \& Evolution 14, 472-477.

Blake, B.J. 1996. Microclimate and prediction of photosynthesis at Marion Island. M.Sc. Thesis, University of the Orange Free State, South Africa.

Boelhouwers, J., Holness, S. \& Sumner, P. 2003. The maritime sub-Antarctic: a distinct periglacial environment. Geomorphology 52, 39-55.

Boelhouwers, J., Meiklejohn, I., Holness, S. \& Hedding, D. 2008. Geology, geomorphology and climate change. In: Chown, S.L. \& Froneman, P.W. (Eds.). The Prince Edward Islands. LandSea Interactions in a Changing Ecosystem. African Sun Media, Stellenbosch, pp. 65-96.

Bonan, G. 2002. Ecological Climatology. Cambridge University Press, Cambridge.

Budd, G.M. 2000. Changes in Heard Island glaciers, King Penguins and Fur Seals since 1947. Papers and Proceedings of the Royal Society of Tasmania 133, 47-60.
Chown, S.L. \& Avenant, N.L. 1992. Status of Plutella xylostella at Marion Island six years after its colonization. South African Fournal of Antarctic Research 22, 37-40.

Chown, S.L. \& Crafford, J.E. 1992. Microhabitat temperatures at Marion Island (46 54' S 37 $45^{\prime}$ E). South African Fournal of Antarctic Research 22, 51-58.

Chown, S.L., Slabber, S., McGeoch, M.A., Janion, C. \& Leinaas, H.P. 2007. Phenotypic plasticity mediates climate change responses among invasive and indigenous arthropods. Proceedings of the Royal Society of London B 274, 2531-2537

Chown, S.L. \& Smith, V.R. 1993. Climate change and the short-term impact of feral house mice at the sub-Antarctic Prince Edward Islands. Oecologia 96, 508-516.

Cooper,J. \& Lutjeharms, J.R.E. 1992. Correlations between seabird breeding success and meteorological conditions at Marion and Gough Islands. South African Fournal of Science 88, 173-175.

CLIVAR 2005. Reports of the Modes of Southern Hemisphere Climate Variability Workshop (27-28th June 2005) and the Third Session of the Clivar/CliC/SCAR Southern Ocean Region Panel Meeting (29-30th June 2005). GLIVAR Publication Series No. 98, International CLIVAR Project Office, Southampton.

Crawford, R.J.M., Rae, C.M.D., Nel, D.C. \& Cooper, J. 2003. Unusual breeding by seabirds at Marion Island during 1997/98. African fournal of Marine Science 25, 453-462.

Davies, K.F. \& Melbourne, B.A. 1999. Statistical models of invertebrate distribution on Macquarie Island: a tool to assess climate change and local human impacts. Polar Biology 21, 240-250. 
Fabricius, A.F. 1957. Climate of the subAntarctic islands. In: Van Rooy, M.P. (Ed.). Meteorology of the Antarctic. Weather Bureau, Pretoria, pp. 111-135.

French, D.D. \& Smith, V.R. 1985. A comparison between northern and southern hemisphere tundra and related ecosystems. Polar Biology 5, 5-21.

Frenot, Y., Gloaguen, J.-C., Cannavacciuolo, M. \& Bellido, A. 1998. Primary succession on glacier forelands in the sub-Antarctic Kerguelen Islands. Fournal of Vegetation Science 9, 75-84.

Frenot, Y., Gloaguen, J.-C., Masse, L. \& Lebouvier, M. 2001. Human activities, ecosystem disturbance and plant invasions in subantarctic Crozet, Kerguelen and Amsterdam Islands. Biological Conservation 101, 33-50.

Frenot, Y., Gloaguen, J.-C., Picot, G., Bougère, J. \& Benjamin, D. 1993. Azorella selago Hook. used to estimate glacier fluctuations and climatic history in the Kerguelen Islands over the last two centuries. Oecologia 95, 140-144.

Frenot, Y., Gloaguen, J.-C. \& Tréhen, P. 1997. Climate change in Kerguelen Islands and colonization of recently deglaciated areas by Poa kerguelensis and P. апnиa. In: Battaglia, B., Valencia, J. \& Walton, D. (Eds.). Antarctic Communities: Species, Structure and Survival. Cambridge University Press, Cambridge, pp. 358-366.

Fyfe, J.C. 2003. Extratropical southern hemisphere cyclones: Harbingers of climate change? Fournal of Climate $\mathbf{1 6}$, 2802-2805.

Fyfe, J.C. \& Saenko, O.A. 2005. Humaninduced change in the Antarctic Circumpolar Current. Fournal of Climate 18, 3068-3073.

Gille, S.T. 2002. Warming of the Southern Ocean since the 1950s. Science 295, 1275-1277.
Gillett, N.P. \& Thompson, D.W.J. 2003. Simulation of recent Southern Hemisphere climate change. Science 302, 273-275.

Gremmen, N.J.M. 1981. The Vegetation of the Sub-Antarctic Islands, Marion and Prince Edward. Junk, The Hague.

Hall, A. \& Visbeck, M. 2002. Synchronous variability in the Southern Hemisphere atmosphere, sea ice, and ocean resulting from the Annular Mode. fournal of Climate 15, 3043-3057.

Hartmann, D.L., Wallace, J.M., Limpasuvan, V., Thompson, D.W.J. \& Holton, J.R. 2000. Can ozone depletion and global warming interact to produce rapid climate change? Proceedings of the National Academy of Sciences of the USA 97, 1412-1417.

Hu, Y.Y. \& Tung, K.K. 2003. Possible ozone-induced long-term changes in planetary wave activity in late winter. fournal of Climate 16, 3027-3038.

Hughes, J.M.R. 1987. The distribution and composition of vascular plant communities on Heard Island. Polar Biology 7, 153-162.

Hugo, E.A., McGeoch, M.A., Marshall, D.J. \& Chown, S.L. 2004. Fine scale variation in microarthropod communities inhabiting the keystone species Azorella selago on Marion Island. Polar Biology 27, 466-473.

Huntley, B.J. 1970. Altitudinal distribution and phenology of Marion Island vascular plants. Tydskrif vir Natuurwetenskap 10, 255-262.

Huntley, B.J. 1971. Vegetation. In: Van Zinderen Bakker, E.M., Sr, Winterbottom, J.M. \& Dyer, R.A. (Eds.). Marion and Prince Edward Islands. Report on the South African Biological and Geological Expeditions 1965-1966. A.A. Balkema, Cape Town, pp. 98-160. 
Huth, R. \& Pokorná, L. 2005. Simultaneous analysis of climatic trends in multiple variables: an example of application of multivariate statistical methods. International fournal of Climatology 25, 469-484.

Huyser, O., Ryan, P.G. \& Cooper, J. 2000. Changes in population size, habitat use and breeding biology of Lesser Sheathbills (Chionis minor) at Marion Island: impacts of cats, mice and climate change? Biological Conservation 92, 299-310.

IPCG 2001. Intergovernmental Panel on Climate Change Working Group I, Climate Change 2001: The Scientific Basis. Cambridge University Press, Cambridge.

Kirkpatrick, J.B. \& Scott, JJ. 2002. Change in undisturbed vegetation on the coastal slopes of Subantarctic Macquarie Island, 1980-1995. Arctic, Antarctic, and Alpine Research 34, 300-307.

Kushner, P.J., Held, I.M. \& Delworth, T.L. 2001. Southern Hemisphere atmospheric circulation response to global warming. Fournal of Climate $\mathbf{1 4}$, 2238-2249.

le Roux, P.C. 2004. Azorella selago (Apiaceae) as a model for examining climate change effects in the sub-Antarctic. M.Sc. Thesis, University of Stellenbosch, South Africa.

le Roux, P.C. \& McGeoch, M.A. 2008. Changes in climate extremes, variability and signature on sub-Antarctic Marion Island. Climatic Change 86, 309-329

le Roux, P.C., McGeoch, M.A., Nyakatya, M.J. \& Chown, S.L. 2005. Effects of simulated climate change on a keystone plant species in the sub-Antarctic. Global Change Biology 11, 1628-1639.

Lutgens, F.K. \& Tarbuck, E.J. 1995. The Atmosphere: An Introduction to Meteorology, 6th edition. PrenticeHall, Englewood Cliffs.
Marshall, G.J., Stott, P.A., Turner, J., Connolley, W.M., King, J.C. \& Lachlan-Cope, T.A. 2004. Causes of exceptional atmospheric circulation changes in the Southern Hemisphere. Geophysical Research Letters 31, Article number L14205.

McGeoch, M.A., le Roux, P.C., Hugo, E.A. \& Chown, S.L. 2006. Species and community responses to short-term climate manipulation: Microarthropods in the subAntarctic. Austral Ecology 31, 719-731.

McGeoch, M.A., le Roux, P.C., Hugo, E.A. \& Nyakatya, M.J. 2008. Spatial variation in the terrestrial biotic system. In: Chown, S.L. \& Froneman, P.W. (Eds.). The Prince Edward Islands. Land-Sea Interactions in a Changing Ecosystem. African Sun Media, Stellenbosch, pp. 245-276.

Meehl, G.A., Hurrell, J.W. \& Van Loon, H. 1998. A modulation of the mechanism of the semiannual oscillation in the Southern Hemisphere. Tellus Series A-Dynamic Meteorology and Oceanography 50, 442-450.

Meehl, G.A., Washington, W.M., Collins, W.D., Arblaster, J.M., Hu, A., Buja, L.E., et al. 2005. How much more global warming and sea level rise? Science 307, 1769-1772.

Mélice, J.-L., Lutjeharms, J.R.E., Goosse, H., Fichefet, T. \& Reason, C.J.C. 2005. Evidence for the Antarctic circumpolar wave in the sub-Antarctic during the past 50 years. Geophysical Research Letters 32, Article number L14614.

Mélice, J.-L., Lutjeharms, J.R.E., Rouault, M. \& Ansorge, I.J. 2003. Sea-surface temperatures at the subAntarctic islands Marion and Gough during the past 50 years. South African fournal of Science 99, 363-366. 
Nyakatya, M.J. \& McGeoch, M.A. 2008. Temperature variation across Marion Islands associated with a keystone plant species [Azorella selago Hook. (Apiaceae)]. Polar Biology 31, 139-151.

O’Hare, G., Sweeney, J. \& Wilby, R. 2005. Weather, Climate, and Climate Change: Human Perspectives. Pearson Education, Harlow.

Pakhomov, E.A. \& Chown, S.L. 2003. The Prince Edward Islands: Southern Ocean oasis. Ocean Yearbook 17, 348-379.

Pakhomov, E.A., McClelland, J.W., Bernard, K., Kaehler, S. \& Montoya, J.P. 2004. Spatial and temporal shifts in stable isotope values of the bottomdwelling shrimp Nauticaris marionis at the sub-Antarctic archipelago. Marine Biology 144, 317-325.

Raphael, M.N. \& Holland, M.M. 2006. Twentieth century simulation of the southern hemisphere climate in coupled models. Part 1: Large scale circulation variability. Climate Dynamics 26, 217-228.

Reason, C.J.C. \& Lutjeharms, J.R.E. 2000. Modelling multidecadal variability in the South Indian Ocean region: local forcing or a near-global mode? South African Fournal of Science 96, 127-135.

Rouault, M., Mélice, J.-L., Reason, C.J.C. \& Lutjeharms, J.R.E. 2005. Climate variability at Marion Island, Southern Ocean, since 1960. Fournal of Geophysical Research-Oceans 110, Article number C05007.

Schulze, B.R. 1971. The climate of Marion Island. In: Van Zinderen Bakker, E.M., Sr, Winterbottom, J.M. \& Dyer, R.A. (Eds.). Marion and Prince Edward Islands. Report on the South African Biological and Geological Expeditions 1965-1966. A.A. Balkema, Cape Town, pp. 16-31.
Shindell, D.T. \& Schmidt, G.A. 2004.

Southern Hemisphere climate response to ozone changes and greenhouse gas increases. Geophysical Research Letters 31, Article number L18209.

Simmonds, I. \& Jones, D.A. 1998. The mean structure and temporal variability of the semiannual oscillation in the southern extratropics. International fournal of Climatology 18, 473-504.

Simmonds, I. \& Keay, K. 2000a. Mean Southern Hemisphere extratropical cyclone behavior in the 40-year NCEP-NGAR reanalysis. Fournal of Climate 13, 873-885.

Simmonds, I. \& Keay, K. 2000b. Variability of Southern Hemisphere extratropical cyclone behavior, 1958-97. Journal of Climate 13, 550-561.

Slabber, S. \& Chown, S.L. 2004. Thermal tolerance and cold hardiness strategy of the subAntarctic psocid Antarctopsocus jeanneli Badonnel. Polar Biology 28, 56-61.

Smith, A.P. 1972. Notes on wind-related growth patterns of paramo plants in Venezuela. Biotropica 4, 10-16.

Smith, V.R. 1992. Surface air temperatures at Marion Island, sub-Antarctic. South African Fournal of Science 88, 575-578.

Smith, V.R. 2002. Climate change in the sub-Antarctic: an illustration from Marion Island. Climatic Change 52, 345-357.

Smith, V.R. \& French, D.D. 1988. Patterns of variation in the climates, soils and vegetation of some subAntarctic and Antarctic islands. South African fournal of Botany 54, 35-46.

Smith, V.R. \& Steenkamp, M. 1990. Climate change and its ecological implications at a sub-Antarctic island. Oecologia 85, 14-24. 
Sumner, P.D., Meiklejohn, K.I., Boelhouwers, J.C. \& Hedding, D.W. 2004. Climate change melts Marion Island's snow and ice. South African fournal of Science 100, 395-398.

Thompson, D.W.J. \& Solomon, S. 2002. Interpretation of recent Southern Hemisphere climate change. Science 296, 895-899.

Thompson, D.W.J. \& Wallace, J.M. 2000. Annular modes in the extratropical circulation. Part I: Month-to-month variability. Fournal of Climate 13, 1000-1016.

Thost, D. \& Allison, I. 2005. The climate of Heard Island. In: Green, K. \& Woehler, E.J. (Eds.). Heard Island: Southern Ocean Sentinel. Surrey Beatty \& Sons, Sydney, pp. 62-68.

Turner, J. 2004. The El Niño-Southern Oscillation and Antarctica. International fournal of Climatology 24, 1-31.

Tweedie, C.E. 2000. Climate change and the autecology of six plant species along an altitudinal gradient on sub-Antarctic Macquarie Island. Ph.D. Thesis, University of Queensland, Australia.

Tweedie, C.E. \& Bergstrom, D. 2000. A climate change scenario for surface air temperature at Subantarctic Macquarie Island. In: Davison, W., Howard-Williams, C. \& Broady, P. (Eds.). Antarctic Ecosystems: Models for Wider Ecological Understanding. New Zealand Natural Sciences, Christchurch, pp. 272-281.

Tyson, P.D. \& Preston-Whyte, R.A. 2000. The Weather and Climate of Southern Africa, 1st ed. Oxford University Press, Oxford.
Van den Broeke, M.R. 1998. The semiannual oscillation and Antarctic climate. Part 1: Influence on near surface temperatures (1957-79). Antarctic Science 10, 175-183.

Van Loon, H. 1967. The half-yearly oscillations in the middle and high southern latitudes and the coreless winter. Fournal of the Atmospheric Sciences 24, 472-486.

Van Zinderen Bakker, E.M., Sr. 1978. Origin and general ecology of the Marion Island ecosystem. South African Journal of Antarctic Research 8, 13-21.

Vaughan, D.G., Marshall, G.J., Connolley, W.M., Parkinson, C., Mulvaney, R., Hodgson, D.A., et al. 2003. Recent rapid regional climate warming on the Antarctic Peninsula. Climatic Change 60, 243-274.

Venegas, S.A. 2003. The Antarctic Circumpolar Wave: a combination of two signals? Fournal of Climate $\mathbf{1 6}$, 2509-2525.

Weimerskirch, H., Inchausti, P., Guinet, C. \& Barbraud, C. 2003. Trends in bird and seal populations as indicators of a system shift in the Southern Ocean. Antarctic Science 15, 249-256.

White, W.B. \& Peterson, R.G. 1996. An Antarctic circumpolar wave in surface pressure, wind, temperature and seaice extent. Nature 380, 699-702.

Yang, E.S., Cunnold, D.M., Newchurch, M.J. \& Salawitch, R.J. 2005. Change in ozone trends at southern high latitudes. Geophysical Research Letters 32, Article number L12812. 